\title{
Mandibuler rekonstrüksiyonlu bir hastada protetik tedavi: Olgu sunumu
}

\author{
Tuğrul Sarı ${ }^{1}$, Ahmet Mihmanlı1, Mehmet Veli Karaaltın²
}

Selcuk Dental Journal, 2015; 3: 130-135

Bașvuru Tarihi: 22 Temmuz 2013 Yayına Kabul Tarihi: 22 Ağustos 2013

\begin{abstract}
Prosthetic treatment of a patient with mandibular reconstruction: A case report

The current standard treatment procedure for oral cancers is the surgical resection of pathological tissues with a certain amount of surrounding healthy tissue and reconstruction of hard and soft tissue defects using free microvascular flaps. However, functional and esthetic outcome of prosthetic treatment following reconstruction procedure is limited because of the lack of proper tissue support after maxillary or mandibular reconstruction and prosthetic treatment often results in nonfunctional prosthesis in such cases. The use of dental implants to support the prosthesis in such patients seems to be the solution of this kind of problems. In this case report, prosthetic treatment of a patient with mandibuler partial resection and reconstruction was presented.
\end{abstract}

\section{KEYWORDS}

Free iliac flap, implant supported overdenture, mandibular reconstruction

Ağız kanserleri için günümüzde standart tedavi kanserli dokuların çevredeki bir kısım sağlıklı doku ile birlikte cerrahi olarak çıkarılmasıdır (Hofmann ve ark 1998). Travma, atrofi, kistik lezyonlar, tümör cerrahisi, osteomiyelit veya osteoradyonekroz gibi sebeplerle mandibulada oluşan büyük kemik defektleri; yüz konturlarının bozulması, dudak desteğinin kaybı, maloklüzyon ve konuşma, yutma ve tükürük kontrolü gibi fonksiyonların bozulması gibi problemlere neden olabilir. Ayrıca dişler ile mandibuler alveol kemiği ve bazal kemiğin kaybı çiğneme etkinliğinde ciddi bozulmalara neden olur (Chiapasco ve ark 2006). Özellikle çiğneme etkinliğinin durumu yiyecek seçimini, hastanın yemek yeme esnasında aldığı keyfi ve sosyal ilişkilerini etkiler (Urken ve ark 1991).

Serbest fleplerin kullanıldığı modern cerrahi teknikler, sert ve yumuşak doku defektlerinin tamiri, çene kemiği bütünlüğünü sağlama ve dil şekliyle ilgili kabul edilebilir sonuçlar elde edilmesini sağlamaktadır. Serbest mikrovasküler flepler, kemikle birlikte üzerindeki periost ve bağlı bulunan kasları da içerecek şekilde osteomusküler veya yüzeyde bulunan cilt dokusunu da içerecek şekilde osteomiyokütanoz flep şeklinde hazırlanarak hem ağız içi hem de ağız dışı yumuşak doku kayıplarının iadesinde de kolaylıkla kullanılabilir (Ferrari ve ark 2013). Serbest mikrovasküler flep tekniklerinin gelişimi, hem kemik hem de yumuşak dokuda oluşan büyük ve kompleks defektlerin tamirinde daha öngörülebilir ve başarılı sonuçlar elde edilmesine olanak sağlamıştır (Ferrari ve ark 2013). Diğer yandan, kanser tedavisinin ertesinde hastanın özgüveni ve psikolojik sağlığını koruması için kabul edilebilir bir yüz görünümü, konuşma yetisi ve çiğneme fonksiyonunun sağlanması gerekir (Schliephake ve ark 1995). Rekonstrüksiyon sonrası yapılan dental protezler bu amaçlara ulaşmak üzere yapılan araçlardır. Ancak, yeni cerrahi rekonstrüksiyon teknikleri bile genellikle duyumotor fonksiyonlarını yeniden sağlamada yetersiz kalmakta, ayrıca çoğu kez dental protezlere yeterli desteği sağlama konusunda da başarısız olabilmektedirler (Garrett ve ark 2006).

Mandibuler rekonstrüksiyonu takiben genellikle karşılaşılan zayıf doku desteği, stabil ve fonksiyonel bir protez yapımının önündeki temel engeldir (Garrett ve ark 2006) ve bu nedenle dental tedaviler yetersiz kalmakta, çoğunlukla da stabil olmayan fonksiyonsuz

\footnotetext{
${ }^{1}$ Bezmialem Vakıf Üniversitesi, Diş Hekimliği Fakültesi, Protetik Diş Tedavisi Anabilim Dalı

${ }^{2}$ Bezmialem Vakıf Üniversitesi, Tıp Fakültesi, Plastik Rekonstrüktif ve Estetik Cerrahi Anabilim Dalı
} 
protezlerin yapımı ile sonuçlanmaktadır (Roumanas ve ark 2006). Bu tip protezlerin stabilitesine katkı sağlamak ve genel başarısını arttırmak amacıyla dental implantların kullanımı son yıllarda giderek önem kazanmıştır (Roumanas ve ark 1997, Chan ve ark 1997). Mevcut dişlerin durumu ve sert ve yumuşak dokunun konfigürasyonuna bağlı olarak dental implantlar; protezlerin destek, stabilite ve retansiyonunu arttırmak için kullanılırlar (Garrett ve ark 2006) ve defekt bölgesinin restorasyonu için yapılan hareketli veya sabit protezlerde karşılaşılan problemlerin üstesinden gelinmesine katkı sağlarlar (Smolka ve ark 2008).

Mandibuler defektlerin rekonstrüksiyonu için greftler elde etmek amacıyla iliak, scapula, radyal önkol ve fibula gibi farklı donör bölgeler kullanılmaktadır. Literatüre bakıldığında mandibuler rekonstrüksiyon için fibula fleplerin ve iliak fleplerin ön plana çıktığı görülmektedir. Fibula greftlerinin, kemiğin uzunluğu ve bükülerek özellikle mandibuler devamlılığı sağlamak üzere şekillendirilmesinin kolaylığı nedeniyle tercih edildiği belirtilmektedir (Mücke ve ark 2009). Ayrıca fibula kemiğinin boyutları ve kaliteli kortikal kemik içeriği, rekonstrüksiyon sonrası implant yerleşimi için de ideal bir zemin oluşturmaktadır (Teoh ve ark 2005). Diğer yandan literatürde, özellikle lateral mandibula rezeksiyonu sonrası kısmen dişli olan hastalarda, fibula greftinin yüksekliğinin dişli bölgeyle birleşim hattında yetersiz kalması nedeniyle iliak greft kullanımının uygun olacağını belirten çalışmalar da vardır. Serbest mikrovasküler iliak flep, elde edilen kemik miktarı ve kalitesi nedeniyle bazı araştırmacılar tarafından ilk tercih edilmesi gereken greft tipi olarak tavsiye edilmiştir (Hotz 1996, Pogrel ve ark 1997). İliak greftler; kansellöz, ince kortikal, kortikokansellöz veya tam kalınlıkta bikortikokansellöz olarak elde edilebilirler. İliak greftin elde edilmesi nispeten kolaydır. Ayrıca doğal şekli mandibula konturlarına uygundur ve kemik miktarı kolaylıkla implant yerleşimine izin verecek şekilde geniştir. Hastaların işlem sonrası yaşadıkları zorluk derecesi ve donör bölge komplikasyonları da nispeten düşüktür (Konstantinovic ve ark 2013).

$\mathrm{Bu}$ vaka raporunda, parsiyel mandibuler rezeksiyon ve rekonstrüksiyon yapılmış bir hastanın implant destekli bir overdenture protezle tedavisi sunulmuştur.

\section{OLGU SUNUMU}

Alt ve üst çene parsiyel dişsizlik şikayetiyle kliniğimize başvuran 56 yaşındaki bayan hastanın ağız içi muayenesi ve radyolojik tetkikleri sonucunda, hastaya daha önce mandibuler rezeksiyon ve rekonstrüksiyon yapıldığı görülmüş, üst çenede kesici dişlerin, alt çenede ise 47 ve 48 numaralı azı dişleri hariç diğer tüm dişlerin eksik olduğu ve alt çene anterior bölgede daha önce yapılan kemik greftini sabitlemek için kullanılan sabitleme plağının hala kemiğe vidalı şekilde olduğu belirlenmiştir (Resim 1 ve Resim 2). Hastanın anamnezi doğrultusunda rezeksiyon ve rekonstrüksiyonun yapıldığı plastik cerrahi kliniğiyle temasa geçilmiş ve 2008 yılında hastanın ağız tabanında yaygın bir şekilde tespit edilen ve patolojik inceleme sonucunda skuamoz hücreli karsinom olarak teşhis edilen lezyon nedeniyle opere edildiği, rezeksiyonu takiben iliak bölgeden alınan serbest mikrovasküler osteomiyokütanöz flep ile mandibuler rekonstrüksiyon yapıldığı bilgisi alınmış ve hastanın geçmiş tıbbi kayıtlarına ulaşılmıştır (Resim 3 ve Resim 4).

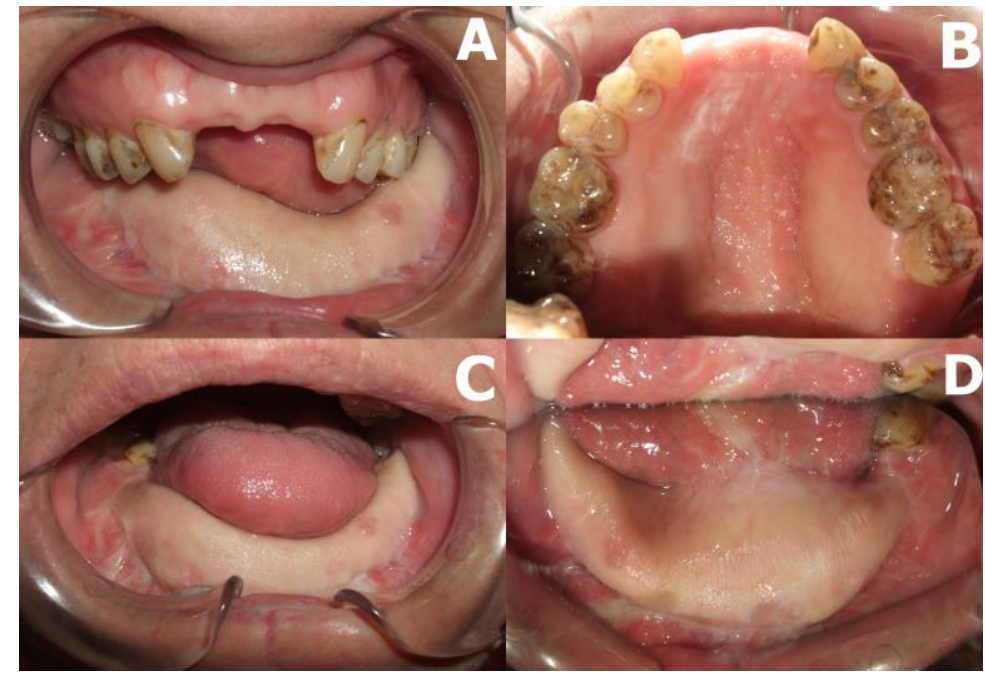

Resim 1.

Kliniğimize başvuru esnasında

A) Maksilla cepheden görünüm

C) Mandibula cepheden görünüm

B) Maksilla oklüzal görünüm D) Mandibula oklüzal görünüm

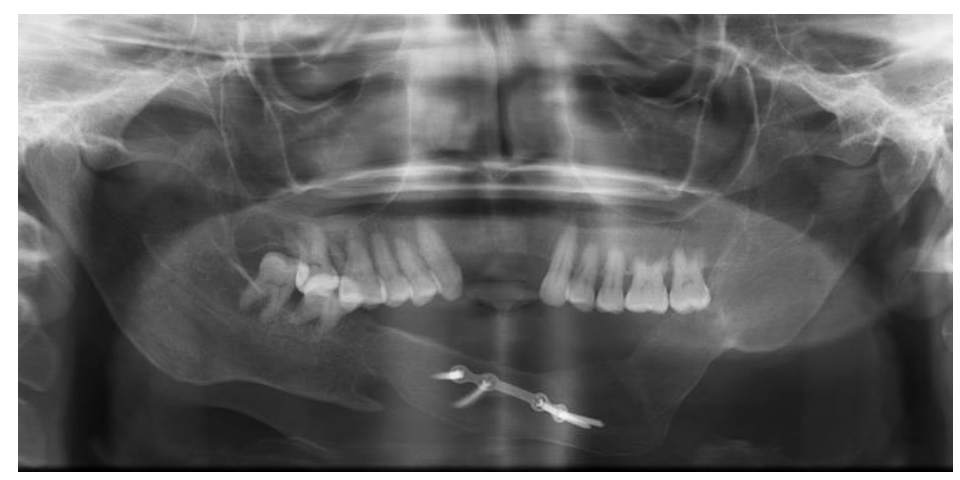

Resim 2

Kliniğimize başvuru esnasında alınan panoramik radyografi 


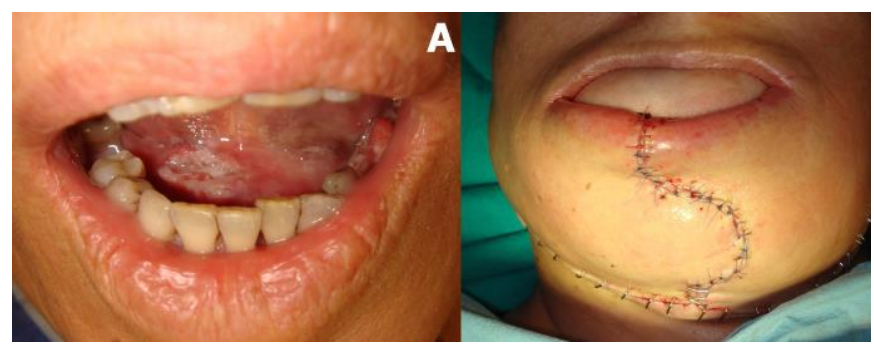

Resim 3.

Hastanın eski kayıtlarından

A) Ağız tabanında skuamoz hücreli karsinom

B) Rezeksiyon ve rekonstrüksiyon cerrahisi sonrasında operasyon bölgesi

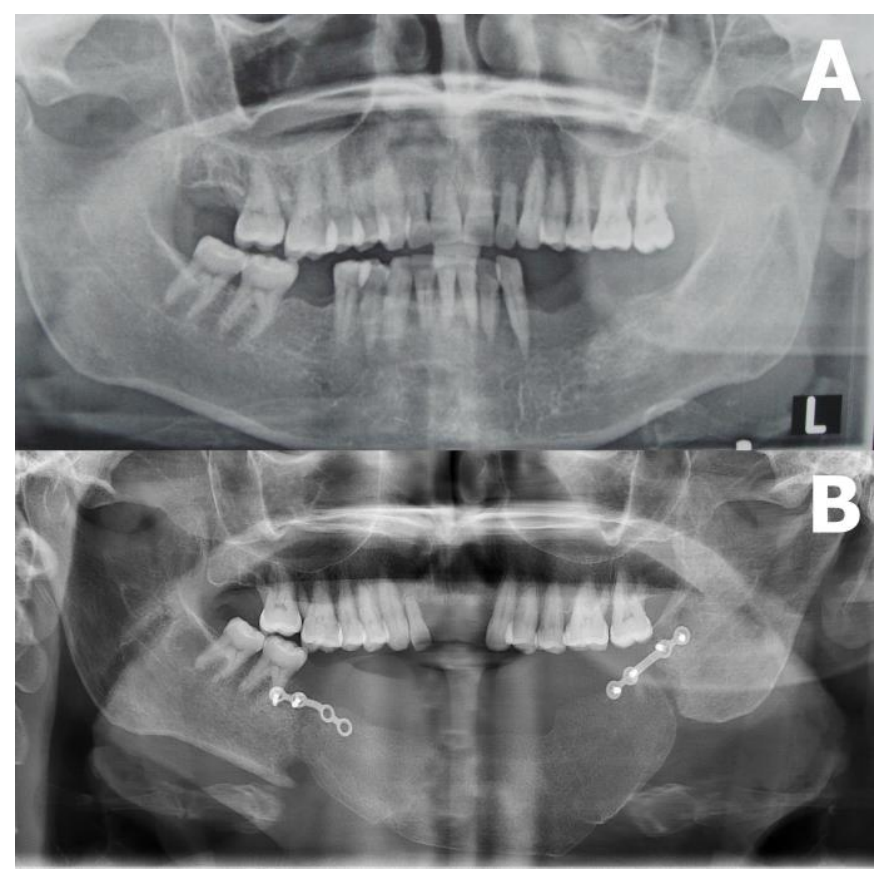

Resim 4.

Hastanın eski kayıtlarından

A) Cerrahi operasyon öncesi panoramik radyografi

B) Cerrahi operasyon sonrası panoramik radyografi

Hastanın şikayetlerine istinaden yapılan protetik değerlendirmede; alt çenenin büyük bir kısmını kapsayan oldukça kalın ve mesnetsiz bir cilt dokusu greftinin varlığı nedeniyle bu bölgede doku destekli bir protez yaparak başarılı olmanın mümkün olmadığı belirlenmiştir. Ayrıca, uygulanan cerrahi prosedürler ve dişsiz geçirilen 4 yılın sonunda hastanın dikey boyutunun ve arklar arası mesafesinin azaldığı, özellikle posterior bölgelerde bu azalmaya ilaveten mevcut maksiller dişlerin de uzaması nedeniyle ciddi bir vertikal mesafe kısıtlılığının olduğu görülmüştür. Ek olarak, rekonstrüksiyon amacıyla bölgeye nakledilen iliak kemik greftinin konturu nedeniyle hastada sahte bir Sınıf 3 kapanış ilişkisinin mevcut olduğu tespit edilmiştir.
Hastanın periodontal tedavisini takiben yapılan cerrahi operasyon esnasında kalınlığı nedeniyle ağız içinde oldukça yer kaplayan cilt dokusu, beslenmesini ve iyileşmesini bozmayacak şekilde olabildiğince inceltilmiş ve iliak kemik grefti bölgesine dört adet $4 \mathrm{~mm}$ çapında ve $14 \mathrm{~mm}$ uzunluğunda dental implant (BlueSKY, Bredent Medical $\mathrm{GmbH}$, Senden, Germany) yerleştirilmiştir. Ayrıca, çekilmesi önceden planlanan dişler de operasyon esnasında çekilmiştir. Yine aynı operasyon esnasında hastanın alt çene anterior bölgesinde bulunan sabitleme plağı da çıkarılmıştır. Operasyon esnasında hissedilen düşük kemik yoğunluğu nedeniyle yaklaşık dört ay kadar beklendikten sonra yapılan radyografik tetkik sonucunda, osseoentegrasyonun tamamlandığı düşünülerek implantların üzeri açılmış ve iyileşme başlıkları takılmıştır.

Vertikal mesafe kısıtlılığ ve karşıt çeneye uzamaları nedeniyle, preperasyon esnasında pulpa perforasyonları ile karşılaşılabileceği düşünülerek, birinci bölgedeki 14,15,16 ve 17 numaralı premolar ve molar dişlere kanal tedavisi yapılmış, sonrasında üst çene dişleri sabit protez yapımı için prepare edilmiş ve ilave reaksiyonlu bir silikon ölçü materyali kullanılarak (Express XT VPS, 3M-ESPE, St. Paul, MN, USA) ölçü alınmıştır. Alt çeneye yapılması planlanan overdenture proteze destek olması için, kemik greftinin pozisyonu nedeniyle birbirlerine paralel yerleştirilemeyen implantların açılanmalarını tolere edebilecek locator ataçmanlar (Locator ${ }^{\circledR}$, Zest Anchors LLC, Escondido, CA, USA) seçilmiştir. İmplantların yerleştirildiği bölgedeki cilt dokusunun kalınlığı nedeniyle, seçenekler arasında mevcut en yüksek dişeti yüksekliğine sahip olan $6 \mathrm{~mm}$ yüksekliğinde locator ataçmanlar seçilmiş ve implant sisteminde sunulan ölçü parçaları kullanılarak bir anatomik ölçü alınmıştır. Takiben hazırlanan akrilik kişisel kaşık ve polieter ölçü materyali (Impregum Penta Soft, 3MESPE, St. Paul, MN, USA) kullanılarak ikinci bir ölçü alınmış ve çalışma modeli elde edilmiştir. Normal implant üstü hareketli protez üretim prosedürlerinden farklı olarak bu hastada; anterior bölgedeki doku kalınlığı nedeniyle, dikey boyut tespiti ve provalar esnasında kaide plağının stabilitesi ile ilgili sorunlar yaşanacağı öngörüldüğü için kaide plağı en başta sıcak akrilikten (Meliodent, Heraus-Kulzer GmbH, Hanau, Germany) muflalama yöntemi ile hazırlanmış ve locator ataçmanların tutucu elemanları en başta kaide plağına sabitlenmiştir. 
Takip eden dönemde yapılan dikey boyut tespiti ve provalar sonucunda, alt çene overdenture protezin dişleri implantlara kıyasla lingualde dizilerek sahte Sınıf 3 kapanış ilişkisi ortadan kaldırımış, alt ve üst protez dişleri baş başa kapanacak şekilde oklüzyon ilişkisi sağlanmıştır. Nihayetinde, üst çenede üç parçalı bir sabit seramik veneer protez ve alt çenede sadece rezeksiyon ve rekonstrüksiyon sürecinden etkilenmeyen retromolar bölgelerde dokudan destek alan, akrilik kaideli (Meliodent, Heraus-Kulzer GmbH) ve implant destekli bir overdenture protez hastaya teslim edilmiştir (Resim 5 ve Resim 6). Illk teslim sonrasında hastanın konuşması ve tükürük kontrolü ile ilgili hafif şikayetleri olduğu görülmüş, takip sürecinde sorunların azaldığı ve protez tesliminden altı ay sonrasındaki randevuda bütün şikayetlerinin ortadan kalktığı öğrenilmiştir. Altı aylık takip sonucunda hastanın implantları ve çevre dokuları ile ilgili hiçbir patolojik durum saptanmamış, hasta memnuniyeti ve oral yetkinliğin tatmin edici seviyede olduğu tespit edilmiştir (Resim 7).

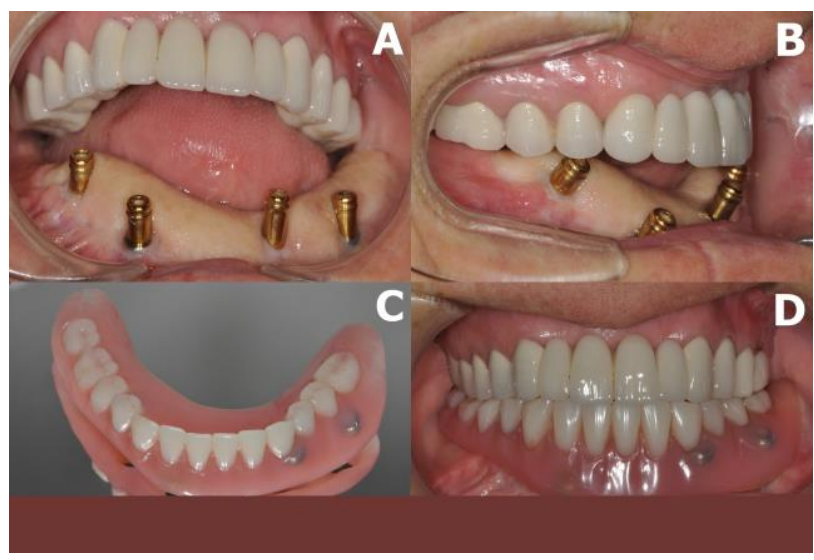

Resim 5.

Protetik tedavi sonrası

A) Maksiller sabit protezler ve locator ataçmanların genel durumu

B) Lateralden locator ataçmanların açılanmaları

C) Mandibuler overdenture protez

D) Kapanış halinde protezler

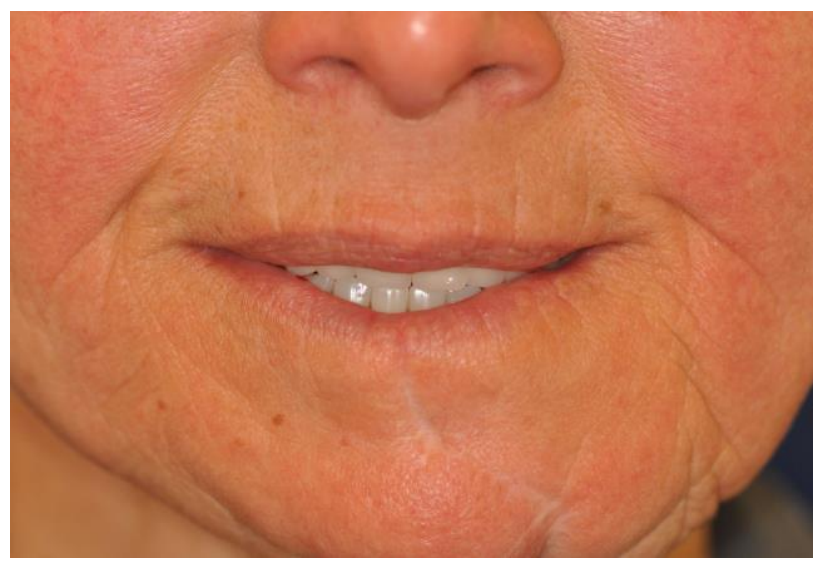

Resim 6

Tedavi sonrasında hastanın yüz görünümü

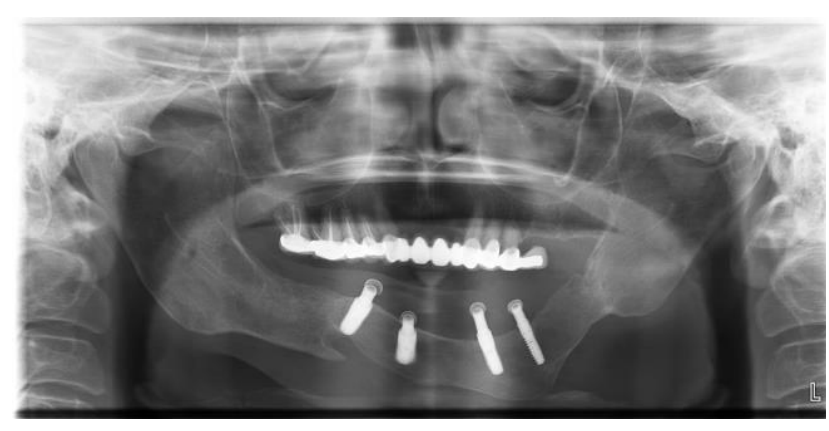

Resim 7.

Altıncı ay kontrol radyografisi

\section{TARTIŞMA}

Oral kanser cerrahisi sonrasında mandibuler veya maksiller rekonstrüksiyon yapılan hastalarda dental implant uygulamasının zamanlaması ile ilgili olarak literatürde farklı görüşler vardır. Bazı raporlarda greftlemeyle eşzamanlı olarak implant yerleşimi tavsiye edilse de (Sclaroff ve ark 1994), özellikle oral kanser hastalarında implant cerrahisi için rezeksiyon ve rekonstrüksiyonun iyileşmesi ve takiben yapılan radyoterapinin sonuçlanmasını beklemek genel kabul gören yaklaşımdır (Garrett ve ark 2006, Marunick ve Roumanas 1999). Greftleme ile eşzamanlı yapılan implantasyon kemiğe daha kolay ulaşım, dişler arası ilişkilerin daha kolay düzenlenmesi ve toplam tedavi zamanının kısaltılması gibi avantajlar sağlasa da (Hundepool ve ark 2008), özellikle kanser cerrahisini takiben uygulanan radyoterapinin hem yumuşak hem de sert dokular üzerinde yaptığı olumsuz etkiler nedeniyle implant prognozu açısından bu uygulama bazı riskler barındırır. $\mathrm{Bu}$ etkiler mukoza enfeksiyonları, ağız kuruluğu, yumuşak dokuların damarlanmasındaki bozulmaya bağlı olarak enfeksiyon direncinin düşmesi, kemiğin üzerinde hiposellüler, hipovasküler ve hipoksemik doku gelişimi ve osteoradyonekroz riski şeklinde özetlenebilir (Hundepool ve ark 2008, Hayter ve Cawood 1996). Bu nedenle bazı araştırmacılar implant cerrahisi için radyoterapi yapılmayan hastalarda 6 ay (Foster ve ark 1999), radyoterapi sonrasında ise en az 12 ay beklenmesini tavsiye etmişlerdir (Hayter ve Cawood 1996). Bizim vakamızda hasta cerrahi tedavi ve radyoterapinin 4 yıl sonrasında kliniğimize başvurduğu için böyle bir çelişki yaşanmamış, yerleştirilen implantların iyileşme sürecinde de herhangi bir aksaklık görülmemiştir.

Mandibuler rekonstrüksiyon yapılmış hastalarda mevcut dişler ile yumuşak ve sert dokuların durumları göz önünde bulundurularak farklı protetik seçenekler arasında tercihler yapılabilir. Bu açıdan 
bakıldığında; sabit protezler genellikle daha konforlu bir kullanım ve daha etkin bir çiğneme gibi avantajlar sağlarken, hareketli protezler ise kaybedilen çevre dokuların iadesini kolaylaştırır, estetik sonuçların ve doğru oklüzal ilişkilerin daha kolay elde edilmesine olanak tanır. Bu vakada bir overdenture protez tercih edilmesinin birkaç sebebi vardır. Bunlar özetle: rezeksiyon sırasında inferior alveoler sinirin feda edilmesi sonucunda tükürük kontrolünü ve konuşmayı zorlaştıracak şekilde gerileyen alt dudağın yeniden desteklenmesi (Garrett ve ark 2006); overdenture protez kaidesi ve dişler vasıtasıyla kaybedilen çevre dokuları da iade ederek yüz yapılarının desteklenmesi; uzun vadede implantların bakımı ile ilgili sorunlarla karşılaşmamak için hareketli bir protezin çıkarılması yoluyla hastanın implantlara erişimi ve kişisel hijyen uygulamalarını takip etmesinin kolaylaştırılması (Garrett ve ark 2006); bu hastaya özel olarak üst çeneye göre daha anteriorda bir ark kurvatürü oluşturan iliak kemik greftinin konumu nedeniyle implantların anteriorda yerleştirilmesi sonucunda oluşan 3. sınıf kapanış durumunun, overdenture protez üzerinde dişleri kolayca daha lingualde pozisyonlandırmak suretiyle baş başa kapanış sağlanarak kompanse edilmesi; yine bu hastada yapılan cerrahiler, uzun süre dişsiz kalma ve ağız içine uygulanan mesnetsiz cilt dokusu greftinin kalınlığı nedeniyle kısıtlanmış olan dikey boyut ve çeneler arası mesafe içerisinde, özellikle posterior bölgede üst dişleri karşılayacak mandibuler azı dişlerinin yerleşimindeki zorluk ve sabit protez yapımı için gereken yüksek maliyet şeklinde sıralanabilir.

Bu vakada dört adet implant ve bu implantların üzerindeki locator ataçmanlar tarafından desteklenen bir overdenture total protez kullanılmıştır. Protez planlaması yapılırken, çenenin büyük bölümünü kapsayan cilt dokusundan doku desteği almanın mümkün olmadığı öngörülerek; sadece posterior retromolar bölgelerde doku desteği olan, kalan diğer kısımlarda tamamen implantların desteklediği bir protez planlaması yapılmış ve bu amaçla, kemiğin mümkün kıldığı en büyük boyutlu implantlar yerleştirilmiştir. İliak kemik greftinin şekli ve konturları nedeniyle birbirleriyle her yönde ciddi açılanmalar yapan implantların açılanmalarını telafi etmek ve hastanın kolaylıkla uyum sağlayabileceği rahat bir protez giriş yolu oluşturmak için locator ataçmanların en uygun seçim olacağı düşünülmüştür. Ayrıca, tutucu parçalarının küçük boyutları nedeniyle, arklar arası mesafe kısıtılığı olan vakalarda locator ataçmanların kullanımı diğer ataçmanlara göre daha kolaydır ve bu vakada da locator ataçmanların bu avantajından faydalanılmıştır.
Literatürde mandibuler rekonstrüksiyonu takiben yapılan implant destekli protezlerin başarısını değerlendiren çok sayıda çalışmaya rastlanmaktadır. Daha önce yapılan bir çalışmada, 10 hasta üzerinde yapılan gözlemler sonucunda, mandibuler rekonstrüksiyonu takiben implant destekli protezlerle tedavi edilen bu hastaların implant destekli protez kullanan diğer bireylere benzer çiğneme fonksiyonu ve oklüzal kuvvetlere sahip oldukları bildirilmiştir (Urken ve ark 1991). Bir başka çalışma sonucunda, implant destekli protezlerin özellikle defekt olan tarafta çiğneme etkinliğine katkı sağladığını ve sonuçta hastaların, cerrahi öncesi döneme yakın bir çiğneme etkinliğine sahip oldukları bildirilmiştir (Roumanas ve ark 2006). Diğer bir çalışmada ise, bir vaka serisinin takibi sonucunda implant destekli protezlerin kullanımıyla hastaların konuşma, beslenme, oral yetkinlik ve yüz görünümü açısından tatmin edildiği ve toplam yaşam kalitesinde belirgin iyileşme sağlandığı belirtilmiştir (Ferrari ve ark 2013). Bizim vakamıda da, protetik rehabilitasyon sonucunda hastanın estetik ve fonksiyonel beklentileri karşılanmış, yüksek derecede hasta memnuniyeti elde edilmiştir.

\section{ÖZET}

\section{Mandibuler rekonstrüksiyonlu bir hastada protetik tedavi: Olgu sunumu}

Günümüzde oral kanser tedavisi için standart uygulama patolojik dokuların çevredeki bir kısım sağlıklı doku ile birlikte cerrahi olarak uzaklaştırılması ve rezeksiyon yapılan bölgedeki sert ve yumuşak doku defektlerinin serbest mikrovasküler flepler kullanılarak rekonstrüksiyonunun yapılmasıdır. Ancak, maksiller veya mandibuler rekonstrüksiyon yapılan bölgedeki yetersiz doku desteği nedeniyle, rekonstrüksiyonu takiben yapılan protetik tedaviden elde edilen fayda sınırlı olmakta ve protetik tedavi genellikle fonksiyonel olmayan bir protezin yapımıyla sonuçlanmaktadır. Protezleri desteklemek için dental implantların kullanımı ise bu tip sorunlara çözüm olacak gibi görünmektedir. $\mathrm{Bu}$ vaka raporunda, mandibuler parsiyel rezeksiyon ve rekonstrüksiyon geçiren bir hastanın protetik tedavisi sunulmaktadır.

\section{ANAHTAR KELIMELER}

İmplant destekli overdenture, mandibuler rekonstrüksiyon, serbest iliak flep 


\section{KAYNAKLAR}

Chan MF, Hayter JP, Cawood JI, Howell RA, 1997. Oral rehabilitation with implant-retained prostheses following ablative surgery and reconstruction with free flaps. Int $\mathrm{J}$ Oral Maxillofac Implants, 12, 820-827.

Chiapasco M, Biglioli F, Autelitano L, Romeo E, Brusati $R$, 2006. Clinical outcome of dental implants placed in fibula-free flaps used for the reconstruction of maxillomandibular defects following ablation for tumors or osteoradionecrosis. Clin Oral Implants Res, 17(2), 220-222.

Ferrari S, Copelli C, Bianchi B, Ferri A, Poli T, Ferri T et al, 2013. Rehabilitation with endosseous implants in fibula free-flap mandibular reconstruction: a case series of up to 10 years. J Craniomaxillofac Surg, 41(2), 172178.

Foster RD, Anthony JP, Sharma A, Pogrel MA, 1999. Vascularized bone flaps versus nonvascularized bone grafts for mandibular reconstruction: an outcome analysis of primary bony union and endosseous implant success. Head Neck, 21(1), 66-71.

Garrett N, Roumanas ED, Blackwell KE, Freymiller E, Abemayor E, Wong WK et al, 2006. Efficacy of conventional and implant-supported mandibular resection prostheses: study overview and treatment outcomes. J Prosthet Dent, 96(1), 13-24.

Hayter JP, Cawood JI, 1996. Oral rehabilitation with endosteal implants and free flaps. Int $\mathrm{J}$ Oral Maxillofac Surg, 25(1), 3-12.

Hoffman HT, Karnell LH, Funk GF, Robinson RA, Menck HR, 1998. The National Cancer Data Base report on cancer of the head and neck. Arch Otolaryngol Head Neck Surg, 124, 951-962.

Hotz G, 1996. Reconstruction of mandibular discontinuity defects with delayed nonvascularized free iliac crest bone grafts and endosseous implants: a clinical report. J Prosthet Dent, 76(4), 350-355.

Hundepool AC, Dumans AG, Hofer SO, Fokkens NJ, Rayat SS, van der Meij EH et al, 2008. Rehabilitation after mandibular reconstruction with fibula free-flap: clinical outcome and quality of life assessment. Int $\mathrm{J}$ Oral Maxillofac Surg, 37(11), 1009-1013.

Konstantinović VS, Todorović VS, Lazić VM, 2013. Possibilities of reconstruction and implant-prosthetic rehabilitation following mandible resection. Vojnosanit Pregl., 70(1), 80-85.

Marunick MT, Roumanas ED, 1999. Functional criteria for mandibular implant placement post resection and reconstruction for cancer. J Prosthet Dent, 82, 107-113.

Mücke T, Haarmann S, Wolff KD, Hölzle F, 2009. Bisphosphonate related osteonecrosis of the jaws treated by surgical resection and immediate osseous microvascular reconstruction. J Craniomaxillofac Surg, 37(5), 291-297.
Pogrel MA, Podlesh S, Anthony JP, Alexander J, 1997. A comparison of vascularized and nonvascularized bone grafts for reconstruction of mandibular continuity defects. J Oral Maxillofac Surg, 55(11), 1200-1206.

Roumanas ED, Markowitz BL, Lorant JA, Calcaterra TC, Jones NF, Beumer J 3rd, 1997. Reconstructed mandibular defects: fibula free flaps and osseointegrated implants. Plast Reconstr Surg, 99, 356-365.

Roumanas ED, Garrett N, Blackwell KE, Freymiller E, Abemayor E, Wong WK et al, 2006. Masticatory and swallowing threshold performances with conventional and implant-supported prostheses after mandibular fibula free-flap reconstruction. J Prosthet Dent., 96(4), 289-297.

Schliephake $H$, Neukam FW, Schmelzeisen $R$, Varoga B, Schneller H, 1995. Long-term quality of life after ablative intraoral tumor surgery. J Craniomaxillofac Surg, 23, 243-249.

Sclaroff A, Haughey B, Gay WD, Paniello R, 1994. Immediate mandibular reconstruction and placement of dental implants. At the time of ablative surgery. Oral Surg Oral Med Oral Pathol, 78, 711717.

Smolka K, Kraehenbuehl M, Eggensperger N, Hallermann W, Thoren $\mathrm{H}$, lizuka $\mathrm{T}$ et al, 2008. Fibula free flap reconstruction of the mandible in cancer patients: evaluation of a combined surgical and prosthodontic treatment concept. Oral Oncol, 44(6), 571-581.

Teoh KH, Huryn JM, Patel S, Halpern J, Tunick S, Wong $\mathrm{HB}$ et al, 2005. Implant prosthodontic rehabilitation of fibula free-flap reconstructed mandibles: a Memorial Sloan-Kettering Cancer Center review of prognostic factors and implant outcomes. Int J Oral Maxillofac Implants, 20(5), 738746.

Urken ML, Buchbinder D, Weinberg H, Vickery C, Sheiner A, Parker R et al, 1991. Functional evaluation following microvascular oromandibular reconstruction of the oral cancer patient: a comparative study of reconstructed and nonreconstructed patients. Laryngoscope, 101, 935-950.

\section{Yazışma Adresi:}

Doç.Dr.Tuğrul SARI

Bezmialem Vakıf Üniversitesi

Diş Hekimliği Fakültesi Protetik Diş Tedavisi A.D.

Adnan Menderes Bulvarı Vatan Caddesi

34093 Fatih, İstanbul

Tel: +90 5327007346

Faks: +902125332326

E-mail: tugrulsari@hotmail.com 